\title{
Potential to Increase Condensate Oil Production by Huff-n-Puff Gas Injection in a Shale Condensate Reservoir
}

\begin{abstract}
This paper presents a huff-n-puff gas injection method to increase condensate production in an Eagle Ford gas condensate reservoir using a simulation approach. The simulation study suggests that the huff time and puff time should be the same. Because of higher compressibility of a gas condensate fluid, either huff or puff time required will be longer than that for a shale oil reservoir. For the studied reservoir, an optimum huff or puff time is about 600 days. However, a shorter time of 300 days is preferable for recouping the cost for facilities. To improve the overall liquid condensate recovery performance, during the last half of the development period, the huff-n-puff may be changed to pressure depletion so that the energy injected earlier can be fully utilized. Other effects such as those of initial water saturation, injection pressure, and gas composition, are also investigated in this paper. The methodology presented in this paper is applicable to other gas condensate reservoirs, and some of results or conclusions may be typical of gas condensate reservoirs.
\end{abstract}

\section{Introduction}

In a gas condensate reservoir, when the pressure is decreased below the upper dew point, liquid condensate forms. Even when the overall reservoir pressure is above the dew point, most often, the pressure near a producer will be below the dew point. Thus, liquid condensate will accumulate near the wellbore. The liquid condensate blocks gas flow, reducing the gas production rate. Thus, less liquid oil can be obtained at the surface (Thomas et al., 1995). Bang et al. (2008) found that condensate buildup in the fractures can significantly reduce the productivity of fractured wells. The steady-state relative permeability even in propped fractures is typically on the order of 0.1 . When oil saturation is below a residual oil saturation, oil cannot be produced using a conventional production method. To solve this problem, several techniques have been used, including gas cycling, drilling horizontal wells, hydraulic fracturing, injection of supercritical $\mathrm{CO}_{2}$, use of surfactant, use of solvents and the use of wettability alteration chemicals. Gas cycling is to keep the reservoir pressure above the dew-point pressure. Drilling horizontal wells and hydraulic fracturing are to reduce the pressure drop. Injection of super-critical $\mathrm{CO}_{2}$ is to reduce the dew-point pressure (Uchenna, 2012). Use of surfactant is to reduce interfacial tension or alter wettability so that the capillary number is increased and the well productivity is increased (Kumar et al., 2006; Ahmed et al., 2011). One common practice in conventional reservoirs is to maintain the reservoir pressure or even the bottom-hole well pressure of the production well above the dew point pressure by gas and/or water flooding (Hernandez et al., 1999). Use of 
chemical stimulation to alter the wettability to non-liquid wetting to remediate the blocking problem was proposed by Kumar et al. (2006), Ahmadi et al. (2011), and Ganjdanesh et al. (2015). Use of solvents to mitigate the impact of liquid blockage has shown positive treatment outcomes in conventional gas condensate reservoirs (Al-Anazi et al., 2005; Sayed and AlMunstasheri, 2014). Recently, Meng et al. (2015) have verified in the laboratory that huff-n-puff gas injection can enhance liquid oil production in shale gas condensate cores.

This paper is to investigate the potential of huff-n-puff gas injection to increase liquid oil production in an Eagle Ford gas-condensate reservoir using a simulation approach.

\section{Setup of a base simulation model}

The current technology to develop shale resources uses horizontal wells with multistage fracturing. To conduct a simulation study, we need to build a model including this technology, and this model needs to be validated. Several authors (Kurtoglu, 2013; Yu et al., 2014) have built models using the Middle Bakken data, but their detailed models are not publically available, and there are no data in the literature that are more complete than the Bakken data. Thus, we will use the Bakken data to build a base model.

In this paper, the compositional simulator, GEM, developed by Computer Modeling Group (CMG) (2014), is used. Because of flow symmetry, a half-fracture connected through a vertical well is simulated. In the Middle Bakken case, a horizontal well is fractured with 15 fracturing stages. It is assumed that only one fracture is generated at one stage, so the production data from this model represents one-thirtieth of the actual production.

The simulation model (reservoir volume) includes two regions: the stimulated reservoir volume and the un-stimulated reservoir volume. The schematic is shown in Figure 1. The model area is $296.25 \mathrm{ft}$ wide in the I direction, $4724 \mathrm{ft}$ in the $\mathrm{J}$ direction with $724 \mathrm{ft}$ in the SRV area, and $50 \mathrm{ft}$ in the K direction (not shown in the figure). In this model, the half-fracture spacing is $296.25 \mathrm{ft}$ in the I direction, the fracture length is $724 \mathrm{ft}$ in the $\mathrm{J}$ direction, and the fracture height is $50 \mathrm{ft}$ in the $\mathrm{K}$ direction. The half-hydraulic fracture width is $0.5 \mathrm{ft}$. One block is used in the $\mathrm{K}$ direction of 50 feet. 


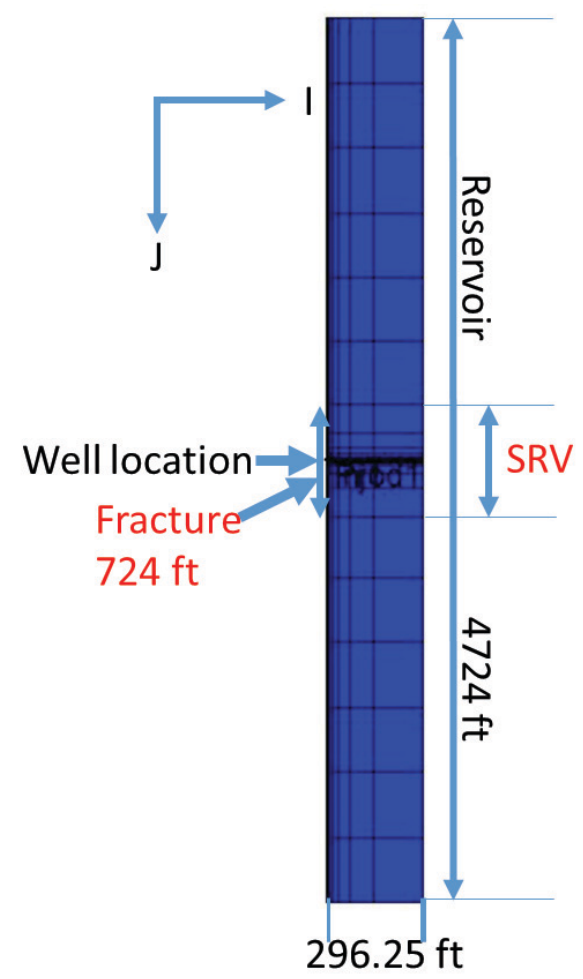

Figure 1 - Schematic of the base model

In this paper, we tried to use the data of the Middle Bakken formation presented by Kurtoglu (2013). Table 1 summarizes the input matrix and fracture properties in the Non-SRV and SRV regions in the Middle Bakken shale. The dual permeability model is used to simulate the naturally and hydraulically fractured shale reservoirs. The shale matrix permeability is 0.0003 $\mathrm{mD}$. The natural fracture effective permeability in the SRV is $0.0313 \mathrm{mD}$. The natural fracture permeability in the un-stimulated reservoir region is $0.00216 \mathrm{mD}$; that is much lower than the stimulated region.

\begin{tabular}{|c|c|c|}
\hline \multicolumn{3}{|c|}{ Table 1 - Matrix and Fracture properties } \\
\hline & Non-SRV & SRV \\
\hline Thickness, $\mathrm{ft}$ & & 50 \\
\hline Matrix Permeability, $\mathrm{mD}$ & $3.0 \mathrm{E}-04$ & $3.0 \mathrm{E}-04$ \\
\hline Matrix Porosity, fraction & 0.056 & 0.056 \\
\hline Fracture Porosity, fraction & 0.0022 & 0.0056 \\
\hline Fracture Permeability, mD & $2.16 \mathrm{E}-03$ & 3.13E-02 \\
\hline Fracture Spacing, $\mathrm{ft}$ & 2.27 & 0.77 \\
\hline $\begin{array}{l}\text { Hydraulic fracture porosity, } \\
\text { fraction }\end{array}$ & & 0.9 \\
\hline $\begin{array}{l}\text { Hydraulic fracture perme } \\
\mathrm{mD}\end{array}$ & & 100 \\
\hline
\end{tabular}

The reservoir fluid composition, the Peng-Robinson EOS parameters, and relative permeabilities are from $\mathrm{Yu}$ et al. (2014). Usethese data and parameters, 1.2 years of production history is able 
to be matched. During the history-match,, the stock-tank oil rate is imposed and the effort is made to match the well bottom-hole pressure. Figure 2 compares the simulated well bottom-hole pressure (line) with the actual data (dotted points). It can be seen that the well bottom-hole pressure is reasonably matched.

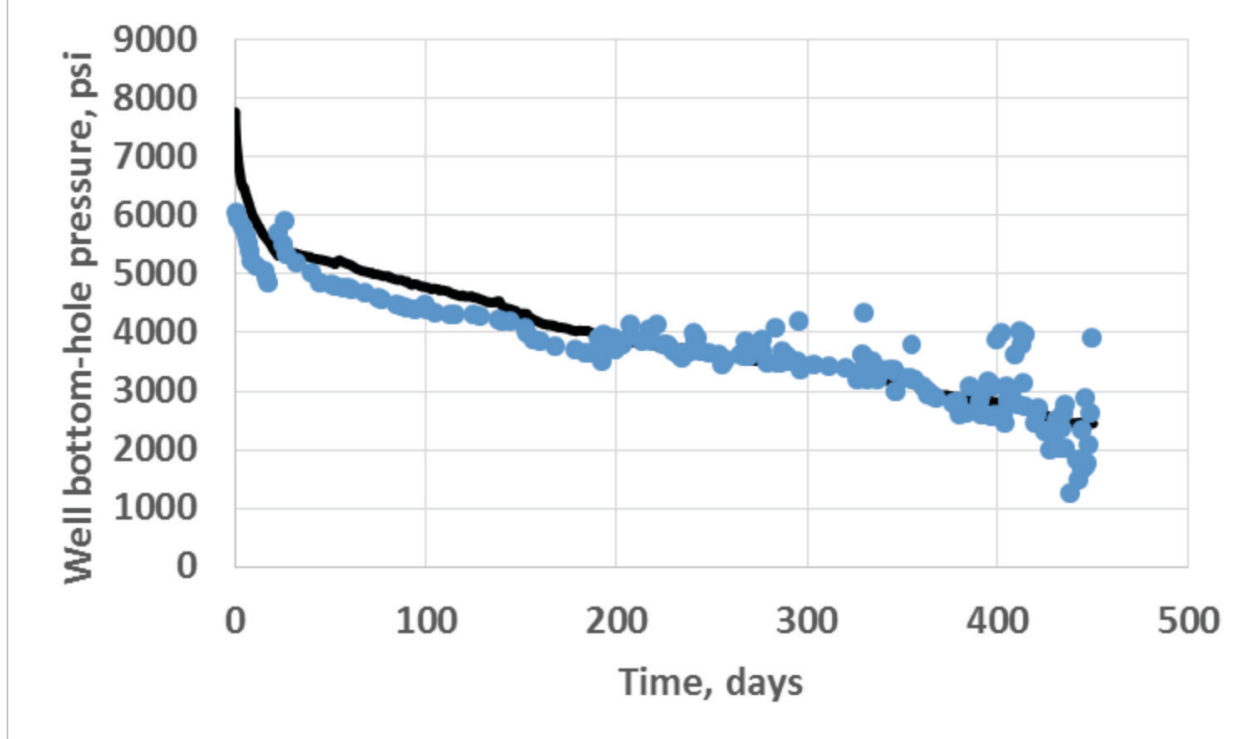

Figure 2 - Well bottom-hole pressure (dot points are actual data, and line is simulated data)

Next, the above calibrated, hydraulically fractured model is used to conduct a simulation study of gas condensate recovery in this paper. The grids, reservoir rock properties, matrix and fracture properties, etc. are unchanged. But gas condensate properties and some of reservoir properties for a gas condensate reservoir in the Eagle Ford formation are used in the model as described next.

For this gas condensate reservoir, the initial reservoir pressure is 9985 psig, the measured upper dew point pressure is $4184 \mathrm{psig}$, and the reservoir temperature is $270{ }^{\circ} \mathrm{F}$. The reservoir fluid composition and the Peng-Robinson EOS parameters are presented in Table 2, and the binary interaction coefficients are shown in Table 3. In Table $2, \mathrm{P}_{c}, \mathrm{~T}_{\mathrm{c}}$ and $\mathrm{V}_{\mathrm{c}}$ are critical pressure, critical temperature and critical volume, respectively, and MW is molecular weight.

\begin{tabular}{|l|l|l|l|l|l|l|l|}
\hline \multicolumn{7}{|c|}{ Table 2 - Peng-Robinson EOS fluid description of the Eagle Ford gas condensate } \\
\hline & $\begin{array}{l}\text { Initial } \\
\text { mole } \\
\text { fraction }\end{array}$ & $\begin{array}{l}\mathrm{P}_{\mathrm{c}} \\
\text { (atm.) }\end{array}$ & $\mathrm{T}_{\mathrm{c}}(\mathrm{K})$ & $\begin{array}{l}\mathrm{V}_{\mathrm{c}} \\
\mathrm{L} / \mathrm{mol})\end{array}$ & $\begin{array}{l}\text { Acentric } \\
\text { Factor }\end{array}$ & $\begin{array}{l}\mathrm{MW} \\
\mathrm{g} / \mathrm{mole}\end{array}$ & $\begin{array}{l}\text { Parachor } \\
\text { coeff. }\end{array}$ \\
\hline $\mathrm{CO}_{2}$ & 0.0188 & 72.80 & 304.2 & 0.0940 & 0.225 & 44.01 & 78.0 \\
\hline $\mathrm{N}_{2}$ & 0.0036 & 33.5 & 126.2 & 0.0895 & 0.04 & 28.01 & 41 \\
\hline $\mathrm{CH}_{4}$ & 0.5695 & 45.4 & 190.6 & 0.099 & 0.008 & 16.04 & 77 \\
\hline
\end{tabular}




\begin{tabular}{|l|l|l|l|l|l|l|l|}
\hline $\mathrm{C}_{2} \mathrm{H}_{6}$ & 0.1431 & 48.2 & 305.4 & 0.148 & 0.098 & 30.07 & 108 \\
\hline $\mathrm{C}_{3} \mathrm{H}_{8}$ & 0.0637 & 41.9 & 369.8 & 0.203 & 0.154 & 44.10 & 150.3 \\
\hline $\mathrm{IC}_{4}$ & 0.0145 & 36.0 & 408.1 & 0.263 & 0.176 & 58.12 & 181.5 \\
\hline $\mathrm{NC}_{4}$ & 0.0244 & 37.5 & 425.2 & 0.255 & 0.193 & 58.12 & 189.9 \\
\hline $\mathrm{IC}_{5}$ & 0.0143 & 33.4 & 460.4 & 0.306 & 0.227 & 72.15 & 225 \\
\hline $\mathrm{NC}_{5}$ & 0.011 & 33.3 & 469.6 & 0.304 & 0.251 & 72.15 & 231.5 \\
\hline FC6 & 0.0177 & 25.97 & 483.1 & 0.344 & 0.330 & 86 & 250.11 \\
\hline FC7 & 0.1194 & 37.16 & 651.8 & 0.381 & 0.36996 & 168 & 278.405 \\
\hline
\end{tabular}

\begin{tabular}{|c|c|c|c|c|c|c|c|c|c|c|c|}
\hline & $\mathrm{CO}_{2}$ & $N_{2}$ & $\mathrm{CH}_{4}$ & $\mathrm{C}_{2} \mathrm{H}_{6}$ & $\mathrm{C}_{3} \mathrm{H}_{8}$ & $\mathrm{IC}_{4}$ & $\mathrm{NC}_{4}$ & $\mathrm{IC}_{5}$ & $\mathrm{NC}_{5}$ & FC6 & FC7 \\
\hline $\mathrm{CO}_{2}$ & 0 & & & & & & & & & & \\
\hline $\mathrm{N}_{2}$ & 0 & 0 & & & & & & & & & \\
\hline $\mathrm{CH}_{4}$ & $1.05 \mathrm{E}-01$ & $2.50 \mathrm{E}-02$ & 0 & & & & & & & & \\
\hline$\overline{\mathrm{C}_{2} \mathrm{H}_{6}}$ & $1.30 \mathrm{E}-01$ & $1.00 \mathrm{E}-02$ & $2.69 \mathrm{E}-03$ & 0 & & & & & & & \\
\hline $\mathrm{C}_{3} \mathrm{H}_{8}$ & $1.25 \mathrm{E}-01$ & $9.00 \mathrm{E}-02$ & $8.54 \mathrm{E}-03$ & $31.66 \mathrm{E}-03$ & 0 & & & & & & \\
\hline $\mathrm{IC}_{4}$ & $1.20 \mathrm{E}-01$ & $9.50 \mathrm{E}-02$ & $1.57 \mathrm{E}-02$ & $25.49 \mathrm{E}-03$ & $1.12 \mathrm{E}-03$ & 0 & & & & & \\
\hline $\mathrm{NC}_{4}$ & 1.15E-01 & $9.50 \mathrm{E}-02$ & $1.47 \mathrm{E}-02$ & $24.91 \mathrm{E}-03$ & $8.66 \mathrm{E}-04$ & $\begin{array}{c}1.59 \mathrm{E}- \\
05\end{array}$ & 0 & & & & \\
\hline $\mathrm{IC}_{5}$ & 1.15E-01 & $1.00 \mathrm{E}-01$ & $12.09 \mathrm{E}-02$ & $28.73 \mathrm{E}-03$ & $2.80 \mathrm{E}-03$ & $\begin{array}{l}3.82 \mathrm{E}- \\
04\end{array}$ & $\begin{array}{c}5.54 \mathrm{E}- \\
04\end{array}$ & 0 & & & \\
\hline $\mathrm{NC}_{5}$ & 1.15E-01 & $1.10 \mathrm{E}-01$ & 1) $2.06 \mathrm{E}-02$ & $28.58 \mathrm{E}-03$ & $2.71 \mathrm{E}-03$ & $\begin{array}{c}3.50 \mathrm{E}- \\
04\end{array}$ & $\begin{array}{c}5.15 \mathrm{E}- \\
04\end{array}$ & $\begin{array}{c}7.17 \mathrm{E}- \\
07\end{array}$ & 0 & & \\
\hline FC6 & 1.15E-01 & $1.10 \mathrm{E}-01$ & 2.53E-02 & $\begin{array}{ll}2 & 1.17 \mathrm{E}-02\end{array}$ & $4.62 \mathrm{E}-03$ & $\begin{array}{c}1.20 \mathrm{E}- \\
03\end{array}$ & $\begin{array}{c}1.49 \mathrm{E}- \\
03\end{array}$ & $\begin{array}{c}2.28 \mathrm{E}- \\
04\end{array}$ & \begin{tabular}{|l|}
2.55 \\
$\mathrm{E}-04$
\end{tabular} & 0 & \\
\hline FC7 & 1.15E-01 & $1.10 \mathrm{E}-01$ & 2.96E-02 & 2 1.47E-02 & $6.57 \mathrm{E}-03$ & $\begin{array}{c}2.29 \mathrm{E}- \\
03\end{array}$ & $\begin{array}{c}2.68 \mathrm{E}- \\
03\end{array}$ & $\begin{array}{c}8.00 \mathrm{E}- \\
04\end{array}$ & \begin{tabular}{|l|}
8.49 \\
E-04
\end{tabular} & 0 & 0 \\
\hline
\end{tabular}

The values of the above tables are obtained by regression to match relative volumes (Figure 3) and liquid dropouts during a constant composition expansion test (Figure 4) at different pressures. The experimental data were measured by a service company. 


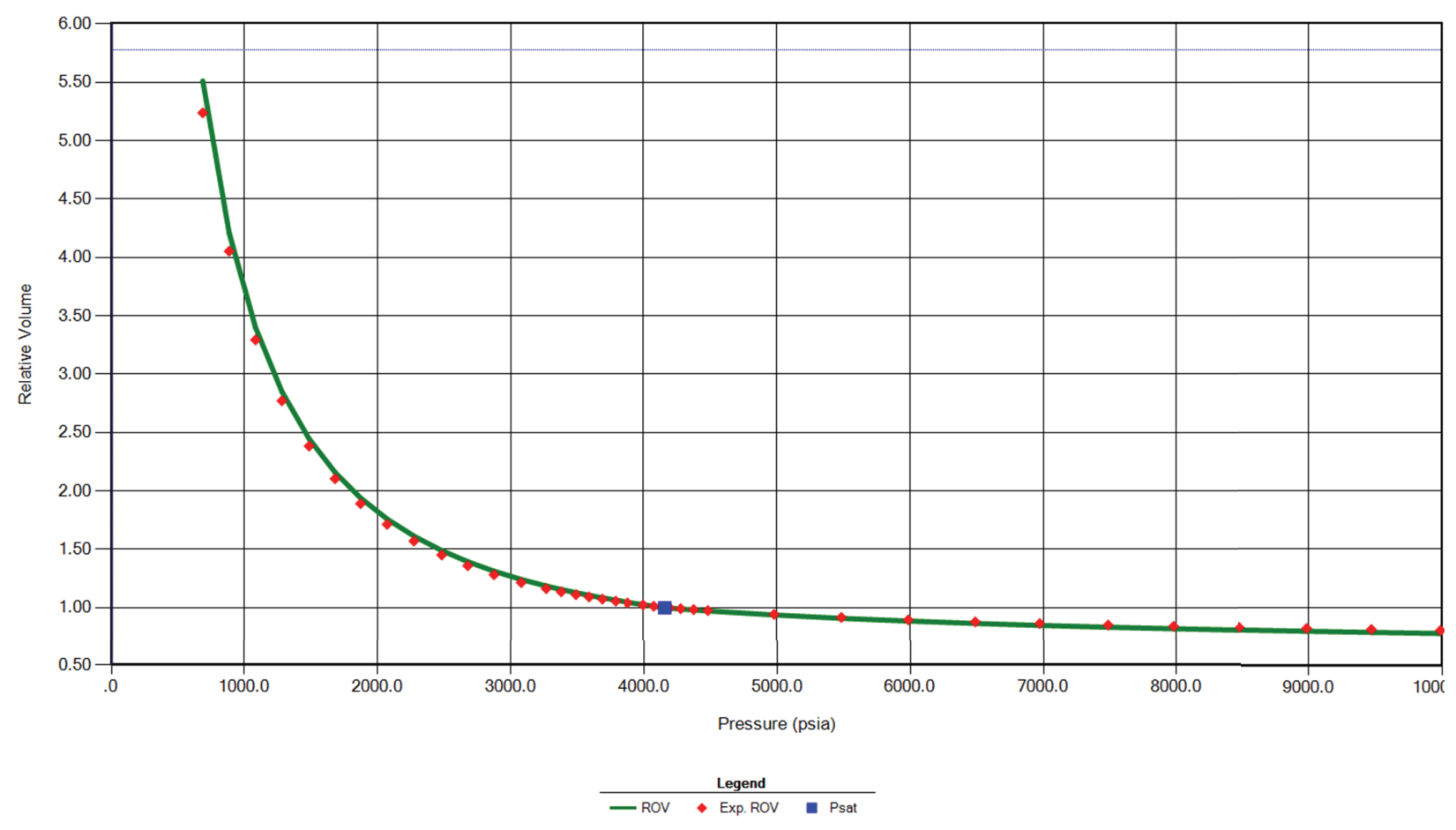

Figure 3 - Relative volume at different pressure

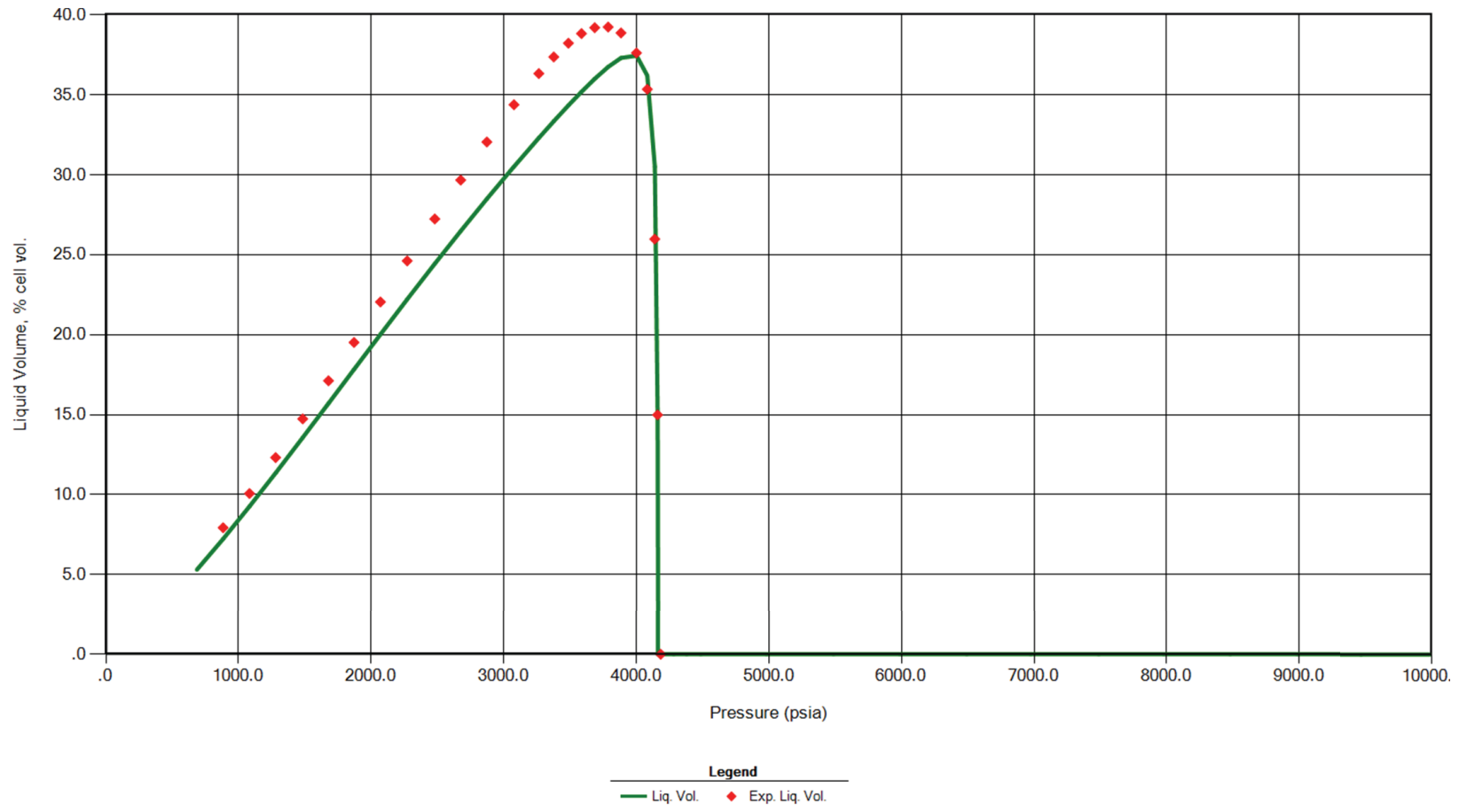

Figure 4 - Liquid dropout at different pressures

\section{Simulation results and discussion}


The reference case is the primary depletion. The reservoir is produced for 10,950 days (30 years). The maximum gas production rate is $300 \mathrm{MSCF} /$ day for a half fracture that is equivalent to 9 MMSCF/day for the whole horizontal well. The minimum bottom-hole pressure is 500 psi. The oil recovery after 30 years is $28.195 \%$, and the gas recovery is $66.164 \%$. Next, we will investigate the effects of huff and puff time, the combination of huff-n-puff and pressure depletion, initial water saturation, and gas composition. Before any huff-n-puff injection, 1,800 days of primary depletion is carried out. At the end of this primary depletion, the average reservoir pressure becomes 4065 psi and the well bottom-hole-pressure is 513 psi.

\section{Effect of huff and puff time}

Next, we need to simulate huff-n-puff gas injection. The maximum injection pressure is set at the initial reservoir pressure of 9985 psi. The maximum gas injection rate for the half-fracture model is $300 \mathrm{MSCF} /$ day, which is equivalent to $9 \mathrm{MMSCF} /$ day for a whole horizontal well with 15 stages (fractures). The maximum gas production rate is the same as the maximum injection rate. The gas injected is methane (lean gas). No soaking time is added in the simulation, as the purpose of the soaking time is not to improve liquid oil recovery (Meng et al., 2015). The huff time and puff time are set the same. The huff or puff time is then changed from 100 days to 1,200 days. The results are shown in Table 4. In the table, the case "Primary" is for primary depletion, for H100P100, the huff time or puff time is 100 days, and the rest of cases are selfexplanatory.

\begin{tabular}{|c|c|c|c|c|c|c|c|c|c|}
\hline \multicolumn{10}{|c|}{ Table 4 - Effect of huff or puff time } \\
\hline Case & $\begin{array}{l}\text { Oil } \\
\text { RF, \% }\end{array}$ & $\begin{array}{l}\text { Gas } \\
\text { RF, \% }\end{array}$ & $\begin{array}{l}\text { Oil } \\
\text { produced } \\
\text {, MSTB }\end{array}$ & $\begin{array}{l}\text { Gas } \\
\text { Produced } \\
\text {, MMSCF }\end{array}$ & $\begin{array}{l}\text { Gas } \\
\text { injected, } \\
\text { MMSCF }\end{array}$ & $\begin{array}{l}\text { Net Gas } \\
\text { produced } \\
\text {, MMSCF }\end{array}$ & $\begin{array}{l}\text { Oil } \\
\text { revenue } \\
\text {, MM\$ }\end{array}$ & $\begin{array}{l}\text { Gas } \\
\text { revenue } \\
\text {, MM\$ }\end{array}$ & $\begin{array}{l}\text { Total } \\
\text { revenue } \\
\text {, MM\$ }\end{array}$ \\
\hline Primary & $\begin{array}{r}28.19 \\
5 \\
\end{array}$ & $\begin{array}{r}66.16 \\
4 \\
\end{array}$ & 26.630 & 346.330 & 0.000 & 346.330 & 2.663 & 1.385 & 4.048 \\
\hline H100P100 & $\begin{array}{r}35.73 \\
8\end{array}$ & $\begin{array}{r}33.21 \\
4\end{array}$ & 33.755 & 1553.900 & $\begin{array}{r}1380.00 \\
0\end{array}$ & 173.900 & 3.376 & 0.696 & 4.071 \\
\hline H300P300 & $\begin{array}{r}42.13 \\
0 \\
\end{array}$ & $\begin{array}{r}27.05 \\
5 \\
\end{array}$ & 39.793 & 1536.600 & $\begin{array}{r}1395.00 \\
0 \\
\end{array}$ & 141.600 & 3.979 & 0.566 & 4.546 \\
\hline H600P600 & $\begin{array}{r}49.10 \\
6 \\
\end{array}$ & 5.999 & 46.382 & 1468.600 & $\begin{array}{r}1437.20 \\
0 \\
\end{array}$ & 31.400 & 4.638 & 0.126 & 4.764 \\
\hline H900P900 & $\begin{array}{r}51.92 \\
5\end{array}$ & $\begin{array}{r}27.84 \\
5\end{array}$ & 49.044 & 1270.700 & $\begin{array}{r}1124.90 \\
0\end{array}$ & 145.800 & 4.904 & 0.583 & 5.488 \\
\hline $\begin{array}{l}\text { H1200P120 } \\
0\end{array}$ & $\begin{array}{r}51.43 \\
5 \\
\end{array}$ & $\begin{array}{r}31.52 \\
4\end{array}$ & 48.582 & 1100.200 & 935.200 & 165.000 & 4.858 & 0.660 & 5.518 \\
\hline $\begin{array}{l}\text { H1500P150 } \\
0\end{array}$ & $\begin{array}{r}49.83 \\
7\end{array}$ & $\begin{array}{r}32.18 \\
6\end{array}$ & 47.073 & 841.480 & 773.000 & 68.480 & 4.707 & 0.274 & 4.981 \\
\hline $\begin{array}{l}\text { H1800P180 } \\
0\end{array}$ & $\begin{array}{r}44.14 \\
5\end{array}$ & -1.786 & 41.696 & 754.280 & 763.630 & -9.350 & 4.170 & -0.037 & 4.132 \\
\hline
\end{tabular}

Table 4 shows that as the huff or puff time is increased up to 900 days, liquid oil recovery is increased, then it is decreased with the huff or puff time. When the huff or puff time is over 900 days, oil recovery decreases. This is because the production rate is high in the beginning of the 
puff period and then sharply decreases. Thus, a too-long puff time will result in a lower oil recovery. The trend for gas recovery to change with huff or puff time does not follow that for oil recovery. As the huff or puff time is increased from 100 to 1,500 days, gas recovery decreases then increases. At 1,800 days, the gas recovery factor is even negative. That means more gas is injected than produced. In the table, the gas recovery is calculated by the net gas produced, divided by the original gas in place. The net gas produced is the produced gas minus the injected gas. If the oil and gas prices are assumed to be \$100/STB and \$4/MSCF, respectively, the oil and gas revenues and their total revenue are shown in Table 4. Here, lower oil and gas prices are not used, because shale resources will most likely not be developed if the prices are lower. Table 4 shows that the total revenue increases with the huff or puff time less than 1,200 days. In practice, a shorter huff time is preferable for a quicker return on the investment. Therefore, from a practical point of view, we may choose the huff or puff time of 300 days.

Comparing the huff-n-puff case, H300P300, with the primary case, the total incremental revenue is only 0.497 MM\$. But this is only from a half fracture. For the whole well of 15 fractures (stages), the total incremental revenue is $14.92 \mathrm{MM \$}$. This shows that the huff-n-puff gas injection could be economical.

\section{Combination of huff-n-puff and pressure depletion}

From Table 4, we can see that one third of the total revenue for the primary case is the produced gas revenue, while the gas revenue for the huff-n-puff cases are marginal. This is because produced gas from huff-n-puff cases is re-injected into the reservoir, maintaining a high reservoir pressure. To make a huff-n-puff project more economical, the reservoir may be depleted after some huff-n-puff cycles.

To prove the above hypothesis, half of the huff-n-puff period (after 6,300 days) of H300P300 case is changed to the pressure depletion period during which no gas is injected. The new case is H300P300-half-dp. The results are shown in Table 5. It can be seen that the oil recovery factor becomes lower, but the gas recovery factor is higher. The total revenue from H300P300-half-dp is a little higher than that from H300P300. We further compare the case H600P600 and H600P600-half-dp in which gas injection (huff) is stopped after 7,200 days. The oil recovery from H600P600-half-dp is a little higher, but the gas recovery is higher than that from H600P600. H600P600-dp4800 is a case with a longer period of depletion (gas injection is stopped after 4800 days). Less oil, and thus less total revenue, is generated from this case compared with those in H600P600-half-dp.

\begin{tabular}{|l|l|l|l|l|l|l|l|l|l|}
\hline \multicolumn{1}{|c|}{ Table 5 - Combination of huff-n-puff and pressure depletion } \\
\hline Case & Oil & Gas & $\begin{array}{l}\text { Oil } \\
\text { produced, } \\
\text { MSTB }\end{array}$ & $\begin{array}{l}\text { Gas } \\
\text { Produced, } \\
\text { MMSCF }\end{array}$ & $\begin{array}{l}\text { Gas } \\
\text { injected, } \\
\text { MMSCF }\end{array}$ & $\begin{array}{l}\text { Net Gas } \\
\text { produced, } \\
\text { MMSCF }\end{array}$ & $\begin{array}{l}\text { Oil } \\
\text { revenue, } \\
\text { MM\$ } \$\end{array}$ & $\begin{array}{l}\text { Gas } \\
\text { revenue, } \\
\text { MM\$ } \$\end{array}$ & $\begin{array}{l}\text { Total } \\
\text { revenue, } \\
\text { MM\$ }\end{array}$ \\
\hline
\end{tabular}




\begin{tabular}{|l|r|r|r|r|r|r|r|r|r|} 
Primary & 28.195 & 66.164 & 26.630 & 346.330 & 0.000 & 346.330 & 2.663 & 1.385 & 4.048 \\
\hline H300P300 & 42.130 & 27.055 & 39.793 & 1536.600 & 1395.000 & 141.600 & 3.979 & 0.566 & 4.546 \\
\hline $\begin{array}{l}\text { H300P300- } \\
\text { half-dp }\end{array}$ & 39.842 & 60.317 & 37.632 & 1035.700 & 820.000 & 215.700 & 3.763 & 0.863 & 4.626 \\
\hline H600P600 & 49.106 & 5.999 & 46.382 & 1468.600 & 1437.200 & 31.400 & 4.638 & 0.126 & 4.764 \\
\hline $\begin{array}{l}\text { H600P600- } \\
\text { half-dp }\end{array}$ & 50.491 & 54.630 & 47.690 & 1183.200 & 897.220 & 285.980 & 4.769 & 1.144 & 5.913 \\
\hline $\begin{array}{l}\text { H600P600- } \\
\text { dp4800 }\end{array}$ & 45.721 & 60.777 & 43.184 & 855.350 & 537.220 & 318.130 & 4.318 & 1.273 & 5.591 \\
\hline
\end{tabular}

\section{Effect of different huff and puff times}

The huff and puff times in the proceeding cases are the same. To optimize a production scheme, one may want to see whether different huff and puff times could improve the performance. Taking H300P300 as a base case, the puff time is changed to 600 days and 150 days in H300P600 and H300P150, respectively. Their results are shown in Table 6. It seems that the performance is best if the huff and puff times are the same.

\begin{tabular}{|l|l|l|l|l|l|l|l|l|r|}
\hline \multicolumn{10}{|c|}{ Table 6 - Different huff and puff times } \\
\hline Case & $\begin{array}{l}\text { Oil } \\
\text { RF, \% }\end{array}$ & $\begin{array}{l}\text { Gas } \\
\text { RF, \% }\end{array}$ & $\begin{array}{l}\text { Oil } \\
\text { produced, } \\
\text { MSTB }\end{array}$ & $\begin{array}{l}\text { Gas } \\
\text { Produced, } \\
\text { MMSCF }\end{array}$ & $\begin{array}{l}\text { Gas } \\
\text { injected, } \\
\text { MMSCF }\end{array}$ & $\begin{array}{l}\text { Net Gas } \\
\text { produced, } \\
\text { MMSCF }\end{array}$ & $\begin{array}{l}\text { Oil } \\
\text { revenue, } \\
\text { MM\$ }\end{array}$ & $\begin{array}{l}\text { Gas } \\
\text { revenue, } \\
\text { MM\$ }\end{array}$ & $\begin{array}{l}\text { Total } \\
\text { revenue, } \\
\text { MM\$ }\end{array}$ \\
\hline H300P300 & 42.130 & 27.055 & 39.793 & 1536.600 & 1395.000 & 141.600 & 3.979 & 0.566 & 4.546 \\
\hline H300P600 & 37.300 & 47.589 & 35.230 & 1149.100 & 900.000 & 249.100 & 3.523 & 0.996 & 4.519 \\
\hline H300P150 & 37.210 & -5.701 & 35.146 & 1105.300 & 1135.100 & -29.800 & 3.515 & -0.119 & 3.395 \\
\hline
\end{tabular}

\section{Effect of maximum injection pressure}

Here, we take the case of huff-n-puff time of 300 days as an example to investigate the effect of injection pressure and rate. For the Primary case and the H300P300-9985psi case, which is the same case as H300P300 listed earlier, the maximum injection pressure is 9,985 psi, and the maximum injection and production gas rate is $300 \mathrm{MSCF} / \mathrm{d}$ for the half-fracture model. In the case of $\mathrm{H} 300 \mathrm{P} 300-7,000 \mathrm{psi}$, the maximum injection pressure is 7,000 psi and the maximum rate is $200 \mathrm{MSCF} / \mathrm{d}$ (correspondingly reduced as well). Table 7 shows that the oil recovery and the total revenue are reduced. The total revenue is close to that in the Primary case. When the injection pressure is reduced to 3,500 psi (with maximum rate being $100 \mathrm{MSCF} / \mathrm{d}$ ), the oil recovery factor and the total revenue are further reduced, being even lower than those from the Primary case. The results here suggest that the injection pressure should be higher to benefit huff-n-puff gas injection. 


\begin{tabular}{|l|l|l|l|l|l|l|l|l|r|}
\hline \multicolumn{10}{|c|}{ Table 7 - Effect of maximum injection pressure and rate } \\
\hline Case & $\begin{array}{l}\text { Oil } \\
\text { RF, \% }\end{array}$ & $\begin{array}{l}\text { Gas } \\
\text { RF, } \%\end{array}$ & $\begin{array}{l}\text { Oil } \\
\text { produced, } \\
\text { MSTB }\end{array}$ & $\begin{array}{l}\text { Gas } \\
\text { Produced, } \\
\text { MMSCF }\end{array}$ & $\begin{array}{l}\text { Gas } \\
\text { injected, } \\
\text { MMSCF }\end{array}$ & $\begin{array}{l}\text { Net Gas } \\
\text { produced, } \\
\text { MMSCF }\end{array}$ & $\begin{array}{l}\text { Oil } \\
\text { revenue, } \\
\text { MM\$ }\end{array}$ & $\begin{array}{l}\text { Gas } \\
\text { revenue, } \\
\text { MM\$ }\end{array}$ & $\begin{array}{l}\text { Total } \\
\text { revenue, } \\
\text { MM\$ }\end{array}$ \\
\hline Primary & 28.195 & 66.164 & 26.630 & 346.330 & 0.000 & 346.330 & 2.663 & 1.385 & 4.048 \\
\hline $\begin{array}{l}\text { H300P300- } \\
\text { 9985psi }\end{array}$ & 42.130 & 27.055 & 39.793 & 1536.600 & 1395.000 & 141.600 & 3.979 & 0.566 & 4.546 \\
\hline $\begin{array}{l}\text { H300P300- } \\
\text { 7000psi }\end{array}$ & 36.251 & 31.352 & 34.240 & 1094.100 & 930.000 & 164.100 & 3.424 & 0.656 & 4.080 \\
\hline $\begin{array}{l}\text { H300P300- } \\
\text { 3500psi }\end{array}$ & 27.956 & 38.149 & 26.405 & 627.310 & 427.620 & 199.690 & 2.641 & 0.799 & 3.439 \\
\hline
\end{tabular}

\section{Effect of initial water saturation}

In Table 4, the initial water saturation, which is the connate water saturation, is 0.2 . Those cases are repeated with the initial water saturation being 0.4 , and their results are shown in Table 8 . Comparing the results in Table 8 with those in Table 4 , we can see that the total revenues are reduced, case-by-case, although the oil recovery factors are higher when the initial water saturation is increased to 0.4 . The higher oil recovery factors are due to the lower initial oil in place. The results from Tables 4 and 8 show that the gas injected case-by-case is similar.

\begin{tabular}{|c|c|c|c|c|c|c|c|c|c|}
\hline \multicolumn{10}{|c|}{ Table 8 - Effect of huff or puff time $\left(S_{w i}=0.4\right)$} \\
\hline Case & $\begin{array}{l}\text { Oil } \\
\text { RF, \% }\end{array}$ & $\begin{array}{l}\text { Gas } \\
\text { RF, \% }\end{array}$ & $\begin{array}{l}\text { Oil } \\
\text { produced } \\
\text {, MSTB }\end{array}$ & $\begin{array}{l}\text { Gas } \\
\text { Produced } \\
\text { MMSCF }\end{array}$ & $\begin{array}{l}\text { Gas } \\
\text { injected, } \\
\text { MMSCF }\end{array}$ & $\begin{array}{l}\text { Net Gas } \\
\text { produced } \\
\text { MMSCF }\end{array}$ & $\begin{array}{l}\text { Oil } \\
\text { revenue } \\
\text {, MM\$ }\end{array}$ & $\begin{array}{l}\text { Gas } \\
\text { revenue } \\
\text {, MM\$ }\end{array}$ & $\begin{array}{l}\text { Total } \\
\text { revenue } \\
\text {, MM\$ }\end{array}$ \\
\hline Primary & $\begin{array}{r}31.92 \\
7 \\
\end{array}$ & $\begin{array}{r}67.94 \\
4 \\
\end{array}$ & 22.617 & 266.617 & 0.000 & 266.617 & 2.262 & 1.066 & 3.328 \\
\hline H100P100 & $\begin{array}{r}38.61 \\
7\end{array}$ & $\begin{array}{r}32.62 \\
5\end{array}$ & 27.356 & 1508.100 & $\begin{array}{r}1380.00 \\
0\end{array}$ & 128.100 & 2.736 & 0.512 & 3.248 \\
\hline H300P300 & $\begin{array}{r}44.78 \\
8\end{array}$ & $\begin{array}{r}23.49 \\
2\end{array}$ & 31.728 & 1487.200 & $\begin{array}{r}1395.00 \\
0\end{array}$ & 92.200 & 3.173 & 0.369 & 3.542 \\
\hline H600P600 & $\begin{array}{r}49.07 \\
5\end{array}$ & -2.599 & 46.353 & 1423.600 & $\begin{array}{r}1437.20 \\
0\end{array}$ & -13.600 & 4.635 & -0.054 & 4.581 \\
\hline H900P900 & $\begin{array}{r}54.47 \\
9 \\
\end{array}$ & $\begin{array}{r}25.00 \\
3\end{array}$ & 38.593 & 1078.200 & 980.060 & 98.140 & 3.859 & 0.393 & 4.252 \\
\hline $\begin{array}{l}\mathrm{H} 1200 \mathrm{P} 120 \\
0\end{array}$ & $\begin{array}{r}53.62 \\
9\end{array}$ & $\begin{array}{r}31.98 \\
3\end{array}$ & 37.991 & 925.910 & 800.350 & 125.560 & 3.799 & 0.502 & 4.301 \\
\hline
\end{tabular}

\section{Effect of injected gases}

Table 9 presents the performance when methane, $\mathrm{CO}_{2}$, and nitrogen are separately injected. The gases produced from different cases are close to each other. The oil recovery from $\mathrm{CO}_{2}$ injection is little higher than that from the methane injection, but is much higher than that from nitrogen injection. The lower oil recovery in the nitrogen injection case is that it is much more difficult for nitrogen to be miscible with liquid oil (high minimum miscible pressure). However, in comparing the liquid oil recovery by $\mathrm{CO}_{2}$ injection with that by methane injection in a gas condensate reservoir, Sheng's (2015) simulation results show that the former is lower. Further 
investigation of the simulation data reveals that the total volume of injected $\mathrm{CO}_{2}$ from the former case is $15 \%$ lower than that from the latter case, because the $\mathrm{CO}_{2}$ injectivity is lower than methane's. In other words, liquid oil recovery will be lower with less gas injected. For shale oil reservoirs, the oil recovery by $\mathrm{CO}_{2}$ injection is observed to be higher than that by methane injection from several of our simulation studies (e.g., Wan et al., 2014). From these data, we can see that the effect of gas composition in gas condensate reservoirs is more complex than that in shale oil reservoirs, which depends on gas injectivity and gas miscibility with liquid drop out.

\begin{tabular}{|l|l|l|l|l|l|l|}
\hline \multicolumn{7}{|c|}{ Table 9 - Effect of injected gases } \\
\hline Case & $\begin{array}{l}\text { Oil } \\
\text { RF, \% }\end{array}$ & $\begin{array}{l}\text { Gas } \\
\text { RF, \% }\end{array}$ & $\begin{array}{l}\text { Oil } \\
\text { produced, } \\
\text { MSTB }\end{array}$ & $\begin{array}{l}\text { Gas } \\
\text { Produced, } \\
\text { MMSCF }\end{array}$ & $\begin{array}{l}\text { Gas } \\
\text { injected, } \\
\text { MMSCF }\end{array}$ & $\begin{array}{l}\text { Net Gas } \\
\text { produced, } \\
\text { MMSCF }\end{array}$ \\
\hline H300P300-C1 & 42.130 & 27.055 & 39.793 & 1536.600 & 1395.000 & 141.600 \\
\hline H300P300-CO2 & 42.263 & 24.720 & 39.918 & 1524.400 & 1395.000 & 129.400 \\
\hline H300P300-N2 & 29.007 & 26.183 & 27.398 & 1532.100 & 1395.000 & 137.100 \\
\hline
\end{tabular}

\section{Conclusions}

Based on this simulation study, the huff time and puff time should be the same for a gas condensate reservoir. For the studied gas condensate reservoir, although a better huff or puff time should be about 900 days, from a practical operation point of view, a shorter time is preferred. Therefore, it is suggested that a huff or puff time of 300 days be used in the studied reservoir. To improve the performance, during the last half of development period, the huff-n-puff may be changed to pressure depletion so that the energy injected during the proceeding gas injection can be fully utilized. Because of higher compressibility of a gas condensate fluid, either huff or puff time is longer than that for a shale oil reservoir.

The maximum injection pressure must be higher than the upper dew point pressure so that the liquid dropout can be re-vaporized.

When the initial water saturation is higher, the revenue generated from huff-n-puff gas injection will be lower, even though the gas injected is similar.

The effect of gas composition in gas condensate reservoirs is more complex than that in shale oil reservoirs, which depends on gas injectivity and gas miscibility with liquid drop out.

\section{Acknowledgment}

The work presented in this paper is supported by the Department of Energy under Award Number DE-FE0024311. 


\section{References}

Ahmadi, M., Sharma, M.M., Pope, G.A., Torres, D., McCulley, C.A., Linnemeyer, H. 2011. Chemical Treatment to Mitigate Condensate and Water Blocking in Gas Wells in Carbonate Reservoirs, SPE Production and Operations, 26(1), 67-74.

Al-Anazi, H.A., Walker, J.G., Pope, G.A., Sharma, M.M., Hackney, D.F. 2005. A Successful Methanol Treatment in a Gas/condensate Reservoir: Field Application, SPE Production \& Facilities, 20(1), 60-69.

Bang, V., Yuan, C., Pope, G.A., Sharma, M.M., Baran, J.R. Jr., Skildum, J., Linnemeyer, H. 2008. Improving Productivity of Hydraulically Fractured Gas Condensate Wells by Chemical Treatment, In: OTC-19599 presented at the Offshore Technology Conference, 5-8 May, Houston, Texas, USA.

Computer Modeling Group, 2014. GEM User Guide, Compositional \& Unconventional Reservoir Simulator, Calgary, Alberta, Canada.

Ganjdanesh, R., Rezaveisi, M., Pope, G.A., Sepehrnoori, K. 2015. Treatment of Condensate and Water Blocks in Hydraulic Fractured Shale Gas-Condensate Reservoirs, In: Paper SPE 17545 presented at the SPE Annual Technical Conference and Exhibition, 28-30 September, Houston, Texas, USA.

Hernandez, I., Farouq Ali, S.M., Bentsen, R.G., 1999. First Steps for Developing an Improved Recovery Method for a Gas Condensate Reservoir, In: Paper PETSOC 95-09 presented at the Annual Technical Meeting of Petroleum Society of Canada, Calgary, Alberta, 14-18 June.

Kumar, V., Pope, G.A., Sharma, M.M. 2006. Improving the Gas and Condensate Relative Permeability Using Chemical Treatments, In: Paper 100529 presented at the SPE Gas Technology Symposium, 15-17 May, Calgary, Alberta, Canada.

Kurtoglu, B. 2013. Integrated reservoir characterization and modeling in support of enhanced oil recovery for Bakken, PhD dissertation, Colorado School of Mines, Golden, Colorado.

Meng, X., Yu, Y., Sheng, J.J., Watson, W., Mody, F. 2015. An Experimental Study on Huff-nPuff Gas Injection to Enhance Condensate Recovery in Shale Gas Reservoirs, In: Paper URTeC 2153322 presented at the Unconventional Resources Technology Conference held in San Antonio, Texas, USA, 20-22 July.

Sayed, M.A., Al-Muntasheri, G.A. 2014. Liquid Bank Removal in Production Wells Drilled in Gas-condensate Reservoirs: A Critical Review, In: Paper SPE 168153 presented at the SPE International Symposium and Exhibition on Formation Damage Control, 26-28 February, Lafayette, Louisiana, USA.

Sheng, J.J. 2015. Increase liquid oil production by huff-n-puff of produced gas in shale gas condensate reservoirs, Journal of Unconventional Oil and Gas Resources, 11, 19-26. 
Thomas, F.B., Zhou, X., Bennion, D.B., Bennion, D.W., 1995. Towards Optimizing Gas Condensate reservoirs, In: Paper PETSOC 95-09 presented at the Annual Technical Meeting of Petroleum Society of Canada, Calgary, Alberta, 7-9 June.

Uchenna, O. 2012. Analysis and Potential of CO2 Huff-n-Puff for Near Wellbore Condensate Removal and Enhanced Gas Recovery, In: Paper SPE 160917 presented at the SPE Annual Technical Conference and Exhibition, 8-10 October, San Antonio, Texas, USA.

Wan, T., Meng, X., Sheng, J.J., Watson, M. 2014. Compositional Modeling of EOR Process in Stimulated Shale Oil Reservoirs by Cyclic Gas Injection, In: Paper SPE 169069 presented at the SPE Improved Oil Recovery Symposium, 12-16 April, Tulsa, Oklahoma.

Yu, W., Lashgari, H., Sepehrnoori, K. 2014. Simulation Study of $\mathrm{CO}_{2}$ Huff-n-Puff Process in Bakken Tight Oil Reservoirs, In: Paper SPE 169575 presented at the SPE Western North American and Rocky Mountain Joint Meeting, 17-18 April, Denver, Colorado, USA. 